\title{
Phytophthora heterospora sp. nov., a New Pseudoconidia-Producing Sister Species of P. palmivora
}

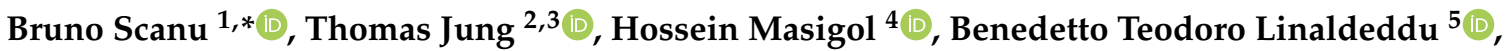 \\ Marília Horta Jung ${ }^{2,3}{ }^{\oplus}$, Andrea Brandano ${ }^{1} \oplus$, Reza Mostowfizadeh-Ghalamfarsa ${ }^{4}{ }^{(}$, Josef Janoušek ${ }^{2}$, \\ Mario Riolo ${ }^{6,7}$ (i) and Santa Olga Cacciola ${ }^{7}$ (D)
}

check for updates

Citation: Scanu, B.; Jung, T.; Masigol, H.; Linaldeddu, B.T.; Jung, M.H.; Brandano, A.; MostowfizadehGhalamfarsa, R.; Janoušek, J.; Riolo, M.; Cacciola, S.O. Phytophthora heterospora sp. nov., a New Pseudoconidia-Producing Sister Species of P. palmivora. J. Fungi 2021, 7, 870. https://doi.org/10.3390/ jof7100870

Academic Editor: Lei Cai

Received: 28 September 2021

Accepted: 14 October 2021

Published: 16 October 202

Publisher's Note: MDPI stays neutral with regard to jurisdictional claims in published maps and institutional affiliations.

Copyright: (c) 2021 by the authors. Licensee MDPI, Basel, Switzerland. This article is an open access article distributed under the terms and conditions of the Creative Commons Attribution (CC BY) license (https:// creativecommons.org/licenses/by/ $4.0 /)$.
1 Department of Agricultural Sciences, University of Sassari, 07100 Sassari, Italy; abrandano@uniss.it

2 Phytophthora Research Centre, Faculty of Forestry and Wood Technology, Mendel University in Brno, 61300 Brno, Czech Republic; thomas.jung@mendelu.cz (T.J.); marilia.jung@mendelu.cz (M.H.J.); josef.janousek@mendelu.cz (J.J.)

3 Phytophthora Research and Consultancy, 83131 Nußdorf, Germany; dr.t.jung@gmail.com (T.J.)

4 Department of Plant Protection, School of Agriculture, Shiraz University, Shiraz 7144165186, Iran; hossein.masigol@gmail.com (H.M.); rmostofi@shirazu.ac.ir (R.M.-G.)

5 Dipartimento Territorio e Sistemi Agro-Forestali, Università Degli Studi di Padova, 35020 Legnaro, Italy; benedetto.linaldeddu@unipd.it

6 Department of Agricultural Science, Mediterranean University of Reggio Calabria, 89122 Reggio Calabria, Italy; mario.riolo@unirc.it

7 Department of Agriculture, Food and Environment, University of Catania, 95123 Catania, Italy; olga.cacciola@unict.it

* Correspondence: bscanu@uniss.it; Tel.: +39-079229296

\begin{abstract}
Since 1999, an unusual Phytophthora species has repeatedly been found associated with stem lesions and root and collar rot on young olive trees in Southern Italy. In all cases, this species was obtained from recently established commercial plantations or from nursery plants. Morphologically, the Phytophthora isolates were characterized by the abundant production of caducous non-papillate conidia-like sporangia (pseudoconidia) and caducous papillate sporangia with a short pedicel, resembling P. palmivora var. heterocystica. Additional isolates with similar features were obtained from nursery plants of Ziziphus spina-christi in Iran, Juniperus oxycedrus and Capparis spinosa in Italy, and mature trees in commercial farms of Durio zibethinus in Vietnam. In this study, morphology, breeding system and growth characteristics of these Phytophthora isolates with peculiar features were examined, and combined mitochondrial and nuclear multigene phylogenetic analyses were performed. The proportion between pseudoconidia and sporangia varied amongst isolates and depended on the availability of free water. Oogonia with amphigynous antheridia and aplerotic oospores were produced in dual cultures with an A2 mating type strain of P. palmivora, indicating all isolates were A1 mating type. Phylogenetically, these isolates grouped in a distinct well-supported clade sister to P. palmivora; thus, they constitute a separate taxon. The new species, described here as Phytophthora heterospora sp. nov., proved to be highly pathogenic to both olive and durian plants in stem inoculation tests.
\end{abstract}

Keywords: oomycete; Peronosporaceae; Phytophthora; clade 4; taxonomy; pseudoconidia; sporangia; multi gene sequencing; phylogenetic analyses; olive; durian

\section{Introduction}

The genus Phytophthora de Bary (Peronosporaceae, Peronosporales, kingdom Stramenipila) is one of the most important groups of plant pathogens, causing a range of diseases in agricultural, horticultural, forest, and natural ecosystems worldwide [1-3]. Initially, the taxonomic description of Phytophthora species was exclusively based on morphological analyses of reproductive structures, such as sporangia, gametangia, chlamydospores, and hyphal swellings, as well as colony morphology and growth rate at different 
temperatures [1]. With the advent of molecular DNA techniques and the development of phylogenetic inference, our understanding of the systematic and diversity of Phytophthora species has changed considerably over time [3-5]. Currently almost 200 species are officially described, grouped into 12 distinct and well supported phylogenetic clades and numerous sub-clades $[4,6]$. The majority of the described Phytophthora species are soilborne and waterborne, primarily responsible for root and collar rots, and occasionally bleeding stem cankers on several plant hosts $[1,3,5,7]$. These species are characterized by the production of persistent sporangia, and their infection occurs through the release of biflagellate zoospores into soil or surface water, which are then attracted by chemical or electrical signals generated by the plant host [8]. Airborne Phytophthora species, on the other hand, produce almost exclusively caducous sporangia and primarily infect aerial parts of plants, causing leaf necroses, shoot blights, fruit rots, and bleeding bark cankers on stem and branches $[1,3,5]$. In this case, infections occur through detached sporangia spread by wind and rain splash that can either germinate directly to produce mycelia (which in turn can differentiate further sporangia) or indirectly by releasing zoospores $[3,7,9]$. Finally, there are some Phytophthora species with a mixed epidemiological strategy, having both caducous and persistent sporangia, thereby behaving as both soil- and airborne pathogens $[3,5,7,10]$.

In 2010, a new disease caused by Phytophthora was reported on 3- to 4-year-old olive (Olea europaea L. cv. Bosana) trees in recently established plantations and commercial nurseries in Sardinia, Italy [11]. Specific symptoms consisted of leaf chlorosis, wilting, defoliation, and dieback, eventually followed by plant death (Figure 1A,B). This syndrome was associated with orange-brown and flame shaped necrosis in the inner bark, originating from root or collar infections and developing up to $50 \mathrm{~cm}$ in the stem (Figure 1C-F). Single necrotic spots, unconnected to collar lesions, often occurred along stems (Figure 1G), indicating that bark necrosis might also have originated from aerial infections. The disease resulted in severe dieback and mortality of olive trees, with an incidence ranging from $20 \%$ to $60 \%$. Isolations from infected bark tissues consistently yielded a Phytophthora species that, based on morphological characters and $99 \%$ similarity of the internal transcribed spacer (ITS) sequences, was initially identified as Phytophthora palmivora (E.J. Butler) E.J. Butler [11]. Most of the isolates, however, behaved unusually—in addition to producing the typical papillate sporangia of $P$. palmivora, the isolates also produced conidia-like sporangia that exclusively germinated directly via germ tubes. This unique feature was already previously reported from a few isolates obtained from root rot of young olive trees in Calabria, Italy, also identified as P. palmivora, although no DNA sequences were generated at that time [12,13]. Due to their resemblance to the conidia of haploid fungi, the conidialike sporangia of this unusual diploid Phytophthora species are in the following named as pseudoconidia. Similar symptoms to those described on olive in Italy were detected in 2013 in the Mekong River delta (Vietnam) on mature, fruit-bearing trees of durian (Durio zibethinus L.), one of the most appreciated and profitable fruit crops in this country. Durian trees showed aerial stem cankers with gum exudates and longitudinal cracking of the bark (Figure $1 \mathrm{H}$ ), from which a Phytophthora species was consistently isolated and morphologically identified as P. palmivora. Additional isolates, with identical ITS sequences to those of the isolates recovered from olive trees, were detected from the crown and root rot of Ziziphus spina-christi (L.) Desf. nursery seedlings in Kazerun County (Fars Province, Iran) in 2011 and from Juniperus oxycedrus L. and Capparis spinosa L. nursery plants in Italy in 2013 and 2014, respectively.

In all cases, the isolates were characterized by the production of pseudoconidia that resembled the sporocysts described for P. palmivora var. heterocystica Babacauh from Theobroma cacao L. in the Ivory Coast in 1983 [1,14], for which, unfortunately, no specimens or DNA sequence data are available. Therefore, in this study, extensive morphological, physiological, and phylogenetic analyses of the unusual Phytophthora isolates from Italy, Iran, and Vietnam were performed, and comparisons were made to P. palmivora, resulting in the description of Phytophthora heterospora sp. nov. 


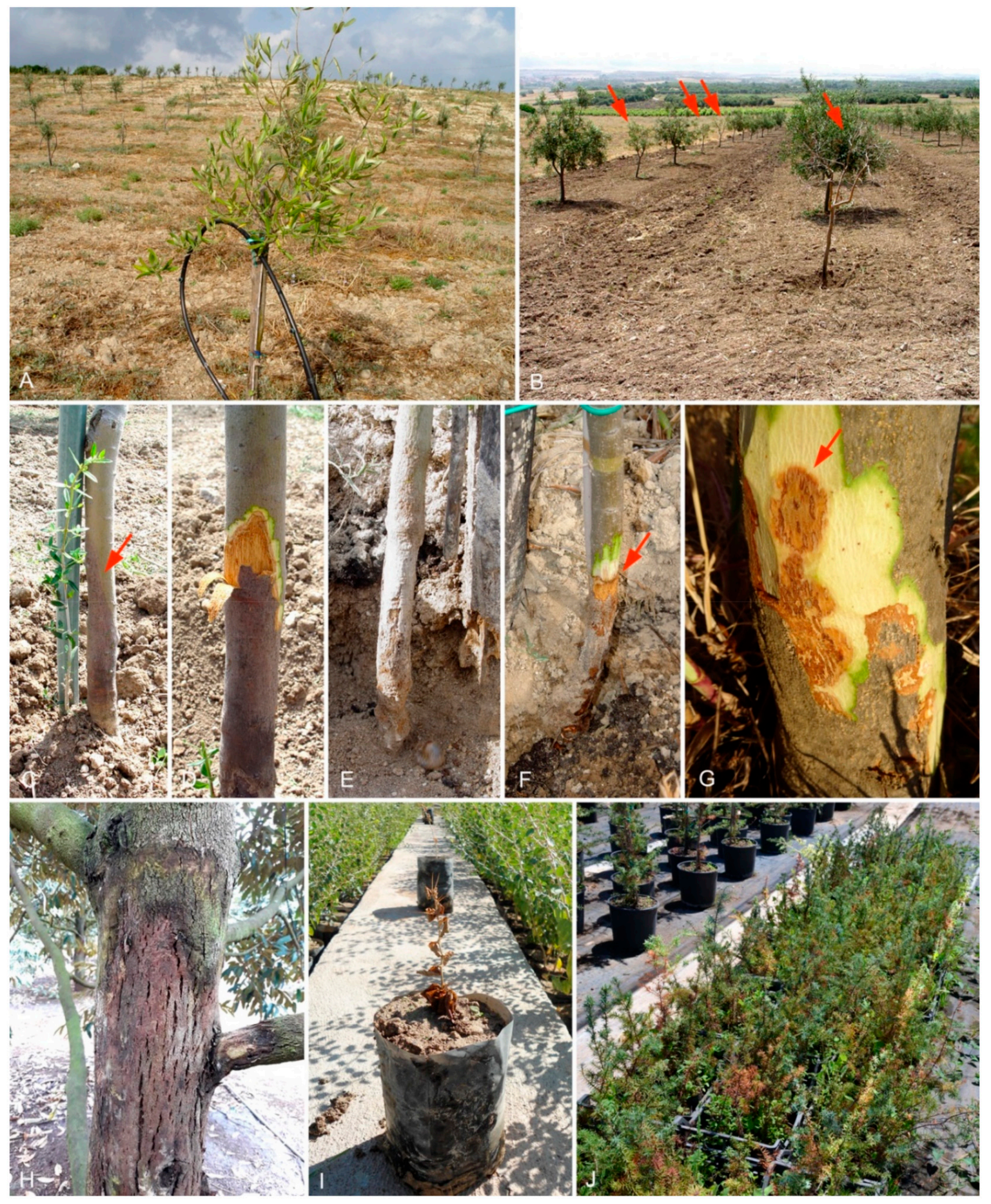

Figure 1. Disease symptoms caused by Phytophthora heterospora on Olea europaea in Italy (A-G): (A) 3- to 4-year-old trees showing chlorosis and increased transparency of the crown; (B) a 5-year-old plantation with dying and dead trees; (C) necrotic outer bark lesion on the lower part of the stem (arrow); (D) orange-brown and flame shaped lesions on the stem; $(\mathbf{E}, \mathbf{F})$ necrotic bark lesions girdling the collar; $(\mathbf{G})$ single-spot bark lesions on the main stem (arrow). (H) Stem canker and scaffold branches on a mature tree of Durio zibethinus in Vietnam. (I) A dead 1-year-old seedling of Ziziphus spina-christi in a nursery in Iran. (J) Two-year-old Juniperus oxycedrus seedlings showing dieback in a nursery in Italy. 


\section{Materials and Methods}

\subsection{Phytophthora Isolation and Culture Maintenance}

From olive trees Phytophthora isolations were mostly made from necrotic bark lesions on stems, collars, and roots. Small pieces from the margins of fresh lesions were cut aseptically and plated onto synthetic mucor agar (SMA) [15]. Soil and fine roots of infected trees were also collected and baited with Rhododendron sp. and citrus leaves using the method originally described by Jung et al. [16]. From C. spinosa, D. zibethinus, J. oxycedrus, and Z. spina-christi seedlings, Phytophthora isolates were obtained by both direct isolation from stem lesions, infected roots, and collar tissues and baiting of the rhizosphere soil using fresh cork oak and citrus leaves as baits and selective SMA and CMA-PARP agar [17]. Any colonies developing from infected tissues and leaf baits on selective media were subcultured onto carrot agar $\left(\mathrm{CA}\right.$; $\mathrm{Oxoid}^{\circledR} \mathrm{n}^{\circ} 3$ agar $16 \mathrm{~g} \mathrm{~L}^{-1}, \mathrm{CaCO}_{3} 3 \mathrm{~g} \mathrm{~L}^{-1}$, blended carrots $200 \mathrm{~g} \mathrm{~L}^{-1}$ ) and cornmeal agar (CMA; Oxoid ${ }^{\circledR}$ ground corn extract $40 \mathrm{~g} \mathrm{~L}^{-1}$, agar $15 \mathrm{~g} \mathrm{~L}^{-1}$ ), incubated at $20^{\circ} \mathrm{C}$ and examined within 4 days using morphological characters for identification [15].

Six isolates of $P$. palmivora, including the representative specimen type "S" (CBS 179.26) proposed by Brasier and Griffin [18], were included for interspecific comparisons (Table 1 and Table S1). Stock cultures were maintained on CA slopes at $15{ }^{\circ} \mathrm{C}$ in the dark and preserved in the culture collections of the University of Sassari, Italy, and the University of Catania, Italy. Dried culture holotypes were lodged with the CBS Herbarium, ex-type and paratype cultures were deposited at the Westerdijk Fungal Biodiversity Institute (CBS; Utrecht, The Netherlands), and the novel taxonomic description and nomenclature were submitted to MycoBank (www.mycobank.org).

Table 1. Details of Phytophthora isolates used in the morphological, growth-temperature, and pathogenicity studies.

\begin{tabular}{|c|c|c|c|c|}
\hline Phytophthora Taxa & Isolate Codes ${ }^{1}$ & Country, Region & Year & Host \\
\hline P. heterospora & PH047 & Italy, Sardinia & 2010 & Olea europaea \\
\hline P. heterospora & PH051 (CBS 148035) & Italy, Sardinia & 2010 & Olea europaea \\
\hline P. heterospora & PH052 & Italy, Sardinia & 2010 & Olea europaea \\
\hline P. heterospora & PH054 (CBS 148034) (T) & Italy, Sardinia & 2010 & Olea europaea \\
\hline P. heterospora & PH057 & Italy, Sardinia & 2010 & Olea europaea \\
\hline P. heterospora & PH211 & Italy, Sardinia & 2013 & Juniperus oxycedrus \\
\hline P. heterospora & 317-A12 (CBS 148036) & Italy, Sicily & 2014 & Capparis spinosa \\
\hline P. heterospora & Palm $2^{2}$ & Italy, Calabria & 1999 & Olea europaea \\
\hline P. heterospora & Campobello $2 \mathrm{~b}$ & Italy, Sicily & 2005 & Olea europaea \\
\hline P. heterospora & DB2 & Vietnam, Mekong Delta & 2013 & Durio zibethinus \\
\hline P. heterospora & $\mathrm{A} 1 \mathrm{~A}$ & Vietnam, Mekong Delta & 2013 & Durio zibethinus \\
\hline P. heterospora & A1B1 & Vietnam, Mekong Delta & 2013 & Durio zibethinus \\
\hline P. heterospora & C2B1 & Vietnam, Mekong Delta & 2013 & Durio zibethinus \\
\hline P. palmivora & CBS $179.26^{3}$ & Sri Lanka, n.a. & 1979 & Theobroma cacao \\
\hline P. palmivora & Phoenix $4{ }^{4}$ & Italy, Sicily & 2005 & Phoenix canariensis \\
\hline P. palmivora & PhoenixF 4 & Italy, Sicily & 2005 & Phoenix canariensis \\
\hline P. palmivora & GRE1 (IMI 390579) 5 & Italy, Sicily & 2002 & Grevillea rosmarinifolia \\
\hline P. palmivora & MD5 (IMI 503890) ${ }^{6}$ & Vietnam, Mekong Delta & 2013 & Artocarpus heterophyllus \\
\hline P. palmivora & MD6 (IMI 503891) ${ }^{6}$ & Vietnam, Mekong Delta & 2013 & Artocarpus heterophyllus \\
\hline P. taxon palmivora-like & PH083 & Italy, Sardinia & 2011 & Arbutus unedo \\
\hline P. taxon palmivora-like & PH090 & Italy, Sardinia & 2011 & Arbutus unedo \\
\hline
\end{tabular}

${ }^{1}$ Abbreviations of isolates and culture collections: CBS = Centraalbureau voor Schimmelcultures, Utrecht, Netherlands; IMI = CABI Bioscience, United Kingdom; other isolate names and numbers are as given by the collectors; $\mathrm{T}=$ ex-type culture. ${ }^{2}$ Isolate from Cacciola et al. [12]. ${ }^{3}$ Isolate from Brasier and Griffin [18]. ${ }^{4}$ Isolates from Pane et al. [19]. ${ }^{5}$ Isolate from Cacciola et al. [20]. ${ }^{6}$ Isolates from Van Tri et al. [21]. 


\subsection{DNA Extraction, Amplification, and Sequencing}

Extraction of mycelial DNA of the P. heterospora and P. palmivora isolates used in the morphological studies was performed using the InstaGene Matrix (Bio-Rad Laboratories, Hercules, CA, USA) and the DNGTM-PLUS (Cinnagen, Tehran, Iran) kits following the manufacturer's instructions. The resulting DNA was stored at $-20^{\circ} \mathrm{C}$, and its quantity and quality were determined using a MD-100 Nanodrop machine (NanoDrop Technologies, Wilmington, DE, USA). The Internal Transcribed Spacers of the ribosomal RNA (ITS) were amplified and sequenced using primers ITS-6 [22] and ITS-4 [23]. Additional gene regions were amplified and sequenced; (1) $\beta$-tubulin (Btub) was amplified using primers Btub F1 and Btub R1 [24], (2) the mitochondrial genes cytochrome c oxidase subunit 1 (cox1) was amplified with primers FM83 and FM84 [25], and (3) NADH dehydrogenase subunit 1 (nadh1) was amplified with NADHF1 and NADHR1 primer [26]. PCR conditions and reaction mixture were as described previously [24,26], except for the amplification conditions for the cox 1 that consisted of 1 cycle of $95^{\circ} \mathrm{C}$ for $2 \mathrm{~min}$, followed by 35 cycles of $94{ }^{\circ} \mathrm{C}$ for $40 \mathrm{~s}, 55^{\circ} \mathrm{C}$ for $50 \mathrm{~s}, 72{ }^{\circ} \mathrm{C}$ for $1 \mathrm{~min}$, and a final extension step of $7 \mathrm{~min}$ at $72{ }^{\circ} \mathrm{C}$. The PCR products were purified using the EUROGOLD gel extraction kit (EuroClone S.p.A., Italy) following manufacturer's instructions. All gene regions were sequenced in both directions with primers used in amplification by the BMR Genomics DNA sequencing service (www.bmrgenomics.it). DNA sequence chromatograms were viewed and edited using BioEdit v. 5.0.6 software [27]. DNA isolation, amplification and sequencing of additional loci of oomycete isolates needed for phylogenetic analysis was performed as described previously [28]. Heterozygous sites observed were labelled according to the IUPAC coding system. All sequences derived in this study were submitted to GenBank (http:/ / www.ncbi.nlm.nih.gov/) and accession numbers are given in Table S1.

\subsection{Phylogenetic Analyses}

For phylogenetic analyses, the sequences obtained in this study were complemented with publicly available sequences of Phytophthora isolates representative of all main phylogenetic clades (Table S1). Furthermore, loci of representative downy mildews, including grass-infecting graminicolous downy mildews (GDM), downy mildews with pyriform haustoria (DMPH), downy mildews with colored conidia (DMCC), and brassicolous downy mildews (BDM), were added to the sequence's dataset (Table S1). The source databases were the GenBank Nucleotide Collection and GenBank Whole-Genome Shotgun contigs. In some cases, sequences from two isolates from the same species were combined into a single sample because neither of them had all desired loci available in GenBank (Table S1); this was only performed if the two isolates shared at least one identical sequence. Nothophytophthora valdiviana sequences were included as outgroup taxon.

The sequences of the loci used in the analyses were aligned using the online version of MAFFT v. 7 [29] by the E-INS-I strategy (ITS) or the G-INS-I strategy (all other loci). Many of the downy mildew species are known to have extremely long ITS sequences of up to more than $3000 \mathrm{bp}$, caused by long repetitive insertions, which can affect both ITS1 and ITS2 [30]. The ITS alignment in this study was manually edited and adjusted, and all insertions longer than $50 \mathrm{bp}$ present exclusively in downy mildews isolates were removed (in total 5729 characters). To sort out the phylogenetic position of $P$. heterospora within phylogenetic clade 4, a concatenated 4-partition dataset of the nuclear (ITS, Btub) and mitochondrial loci (cox1, nadh1), consisting of 4161 characters, was analyzed.

Bayesian Inference (BI) analysis was performed using MrBayes version 3.2.7 [31,32] into partitions with the GTR Gamma + I nucleotide substitution model. Four Markov chains were run for $20 \mathrm{M}$ generations, sampling every 1000 steps and with a burn in at 9000 trees. Maximum Likelihood (ML) analysis was carried out using the raxmlGUI v. 2.0 [33] implementation of RAxML [34] with a GTR Gamma + I nucleotide substitution model. There were 10 runs of the ML and bootstrap (thorough bootstrap) analyses with 1000 replicates used to test the support of the branches. Phylogenetic trees were visualized in Mesquite version 3.61 [35] and/or MEGA X version 10.2.6 [36] and were edited in figure 
editor programs. Datasets presented and original trees deriving from BI and ML were deposited at Dryad Dataset (https:/ / datadryad.org).

\subsection{Morphological Characterization and Cardinal Temperature for Growth}

Ten isolates of $P$. heterospora and four isolates of $P$. palmivora were included in the morphological studies. Measurements and photos of morphological structures were made at $400 \times$ magnification and recorded using a digital camera Leica DFC495 connected to a Leitz Diaplan compound microscope (Leitz, Germany) and Leica Application Suite imaging software v.4.5.0 (Leica Microsystems, Switzerland). Pseudoconidia and sporangia were examined both on solid CA after 7 days at $20^{\circ} \mathrm{C}$ and from CA plugs (10 mm diameter) placed in $60 \mathrm{~mm}$ Petri dishes flooded with nonsterile soil extract water. Chlamydospores and hyphal swellings were examined directly on CA plates, if present. Length (l), breadth (b), 1/b ratio, pedicel length, and characteristic features of pseudoconidia and sporangia, as well as shape and diameters of chlamydospores and hyphal swellings of 50 mature structures randomly selected, were recorded for each isolate [37]. In addition, the proportion between pseudoconidia and sporangia was assessed across the isolates, both in water and on solid CA. Specifically, four $1 \mathrm{~mm}^{2}$ discs were taken from each P. heterospora isolate listed in Table 1 and mounted on glass slides with sterile water. The number of sporangia contained in each $1 \mathrm{~mm}^{2}$ was counted using a Leitz Diaplan compound microscope. The morphology of pseudoconidia was observed also through a scanning electron microscopy (SEM). CA plugs of $4 \times 4 \mathrm{~mm}$ taken from 7-day-old cultures were fixed in $2 \%$ glutaraldehyde in $0.1 \mathrm{M}$ sodium-cacodylate buffer (EMS), $\mathrm{pH} 7.2$, for $1 \mathrm{~h}$ at $4{ }^{\circ} \mathrm{C}$ and then post-fixed in $1 \%$ osmium tetroxide (EMS) for $1 \mathrm{~h}$ at $4{ }^{\circ} \mathrm{C}$. After dehydration in graded ethanol and critical point drying using $\mathrm{CO}_{2}$ (Emscope-CPD 750), the samples were attached by CCC carbon adhesive directly on the microscope stubs, coated with vacuum evaporated gold (Emscope-SM 300), and observed using a Field Emission Scanning Electron Microscope (FESEM).

The sexual compatibility type of all P. heterospora isolates was determined in dual culture with known A1 and A2 tester strains of P. cinnamomi (P904, P1889) on CA [15]. Selfed gametangia of the six representative isolates were induced on $35 \mathrm{~mm}$ plates containing $10 \mathrm{~mL} C A$ in polycarbonate membrane tests (Whatman Nuclepore ${ }^{\mathrm{TM}}$ Track-Etched Membranes, Sigma-Aldrich, St. Louis, MO, USA) with opposite mating type tester strains of P. palmivora (CBS 179.26). Paired cultures were incubated at $20^{\circ} \mathrm{C}$ in darkness and scored for gametangial formation after 15-20 days. Fifty gametangia were chosen at random, and dimensions and characteristic features of antheridia, oogonia, and oospores were measured and recorded at $400 \times$ magnification. The oospore aplerotic index and wall index were calculated according to Dick [38].

Colony morphologies were characterized from 4-day-old cultures incubated at $20^{\circ} \mathrm{C}$ in the dark on CA, V8-juice agar (V8A; filtered V8 juice $100 \mathrm{~mL} \mathrm{~L}^{-1}, \mathrm{CaCO}_{3} 0.1 \mathrm{~g} \mathrm{~L}^{-1}$ ) [15], potato dextrose agar (PDA; $39 \mathrm{~g} \mathrm{~L}^{-1}$ ), and malt extract agar (MEA; $16 \mathrm{~g} \mathrm{~L}^{-1}$ ) (all agar media were sourced from Oxoid ${ }^{\circledR}$, Basingstoke, UK). Temperature-growth rate studies were performed on CA according to Scanu et al. [15]. Each isolate was incubated with three replicates at $5,10,15,20,25,27.5,30,32.5,35$ and $40{ }^{\circ} \mathrm{C}\left(\right.$ all $\left.\pm 0.5^{\circ} \mathrm{C}\right)$.

\subsection{Pathogenicity Test}

To fulfill Koch's postulates, the pathogenicity of three representative isolates of $P$. heterospora was tested against 2-year-old olive (Olea europaea cv. Bosana) saplings. One isolate of P. palmivora and one isolate of $P$. taxon palmivora-like were included in the trial. The experimental design consisted of five replicates (saplings) per isolate, and five saplings, inoculated with a CA plug, were used as negative controls. A $5 \mathrm{~mm}$ diameter hole through the bark of the sapwood stem was made using a cork borer. Then, a $5 \mathrm{~mm}$ agar plug taken from the margin of 4-day-old cultures grown on CA was inserted into the wound. Soon after inoculation, wounds were wrapped with sterile damp cotton wool and covered with aluminum foil and parafilm. Saplings were maintained in the laboratory for 2 months in 
daylight and at temperatures ranging between 25 and $30{ }^{\circ} \mathrm{C}$. At the end of the experiment, the outer bark was stripped and the necrotic lesion area surrounding each inoculation point was traced and then measured using APS Assess 2.0 software (APS Press) [10]. Re-isolation was attempted by transferring ten pieces taken from the margin of each lesion to SMA and incubating the plates at $20^{\circ} \mathrm{C}$.

The pathogenicity of the P. heterospora isolate DB2 was tested on 12-year-old durian trees in a commercial farm in the Dong Nai province (southern Vietnam). Inoculation was performed in December 2013 by underbark-inoculation. A colony plug ( $5 \mathrm{~mm}$ diam) was inserted under the bark of branches of the trees (two trees and three branches for each tree). The bark disk was put back in place to plug the wound, which was covered with a sterile moist cotton plug and sealed with adhesive tape. Branches inoculated with sterile agar served as a control. During the experiment, temperature ranged between $25^{\circ} \mathrm{C}$ (night) and $32.5^{\circ} \mathrm{C}$ (day). Natural light with around $12 \mathrm{~h}$ of light. Symptoms were first recorded 15 days after inoculation. For measuring the size of the necrotic lesions, the bark was removed 30 days after inoculation.

\section{Results}

\subsection{Phylogeny}

The aligned datasets for the nuclear (ITS, Btub) and mitochondrial (cox1, nadh1) genes consisted of 1101, 918, 1346, and 796 characters, respectively. Across the concatenated 4141 characters alignment of all four gene regions, $P$. heterospora showed 21-28 unique polymorphisms (Table S2). All isolates of $P$. heterospora were identical across all four loci apart from positions 307 and 438 in Btub, which were heterozygous in several isolates, and position 660 in Btub, where isolate PH211 had an A instead of a G. The mitochondrial sequences of the two isolates PH083 and PH090 from A. unedo, informally designated here as $P$. taxon palmivora-like, were identical to those of $P$. heterospora.

To resolve the phylogenetic positions of P. heterospora within the genus Phytophthora and its separation from P. palmivora, a concatenated nuclear and mitochondrial 4-partition dataset (4141 characters) was analyzed. Support for terminal clades and their clustering was similar in both BI and ML analyses, and the ML analysis is presented here with both ML bootstrap and BI posterior probability values included (Figure 2, Dryad Dataset, https://doi.org/10.5061/dryad.1jwstqjvx). The isolates of $P$. heterospora formed a fully supported monophyletic cluster (BI posterior probability $=1.00$, ML bootstrap $=99 \%$ ), which resided in clade 4 in a close position to P. palmivora. Interestingly, isolate PH090 clustered in a strongly supported basal position to P. heterospora, intermediate between the latter and P. palmivora and, hence, is designated here as $P$. taxon palmivora-like (Figure 2). Amongst the isolates of $P$. palmivora, there was considerably higher intraspecific variability than in P. heterospora, with the two isolates from Artocarpus heterophyllus (MD5 and MD6) forming a distinct lineage (Figure 2). The phylogenetic analyses of the 65-taxon dataset, which included Phytophthora, Nothophytophthora, and representatives of all downy mildew groups, placed the latter into two fully supported monophyletic clades nested within the genus Phytophthora. The DMCC, GDM, and BDM clade resided in sister position to a large cluster comprising Phytophthora clades 1-5, 12, and 14 and the DMPH, whereas the latter clustered together with the obligate biotrophic Phytophthora cyperi from clade 14 in a sister position to clade 1 (Figure 2).

\subsection{Taxonomy}

Phytophthora heterospora Scanu, Cacciola, Linaldeddu \& Jung sp. nov. (Figures 3-5). MycoBank MB 841284.

Etymology: the name refers to the production of a variety of different spores including pseudoconidia, zoospore-releasing sporangia, chlamydospores, and oospores.

Holotype: Italy, Sardinia, Sorso; isolated from a bark lesion on a young olive tree. Collected: B. Scanu, 2010; CBS H-24777 (holotype, dried culture on CA, Herbarium CBSKNAW Fungal Biodiversity Centre), CBS $148034=$ PH054 (ex-holotype culture). ITS, 
Btub, cox1 and nadh1 sequences GenBank MT232393, MZ782807, MZ782828, MZ782849, respectively.

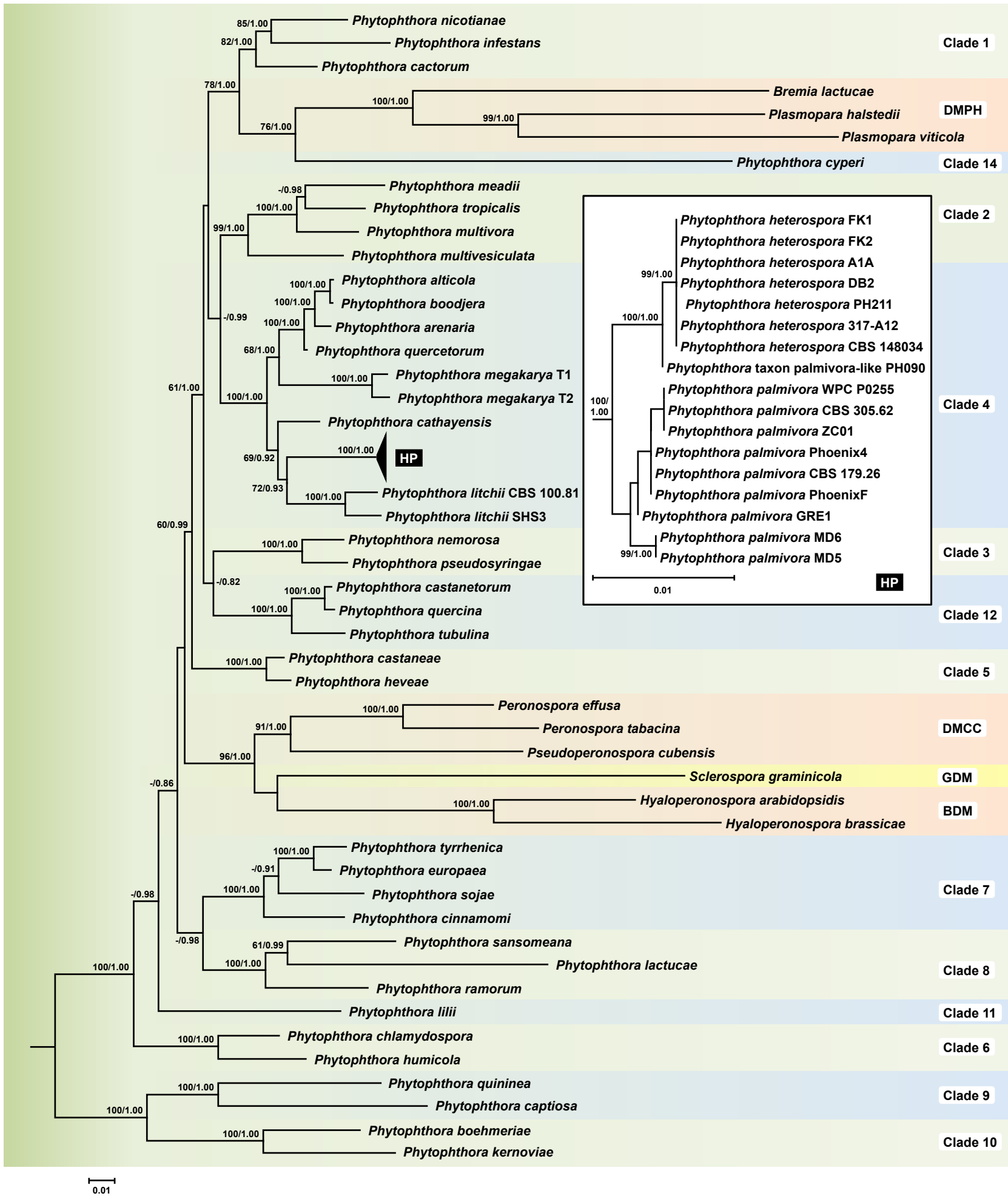

Figure 2. Fifty percent majority rule consensus phylogram derived from maximum likelihood analysis of a concatenated four-locus (ITS, Btub, cox1, nadh1) dataset of representative species from phylogenetic clades 1-12 and 14 of Phytophthora and the four downy mildew groups DMPH, DMCC, GDM, and BDM. Maximum likelihood bootstrap values and Bayesian posterior probabilities are indicated but not shown below $60 \%$ and 0.80 , respectively. Nothophytophthora valdiviana was used as outgroup taxon (not shown). Scale bar $=0.01$ expected changes per site per branch. 

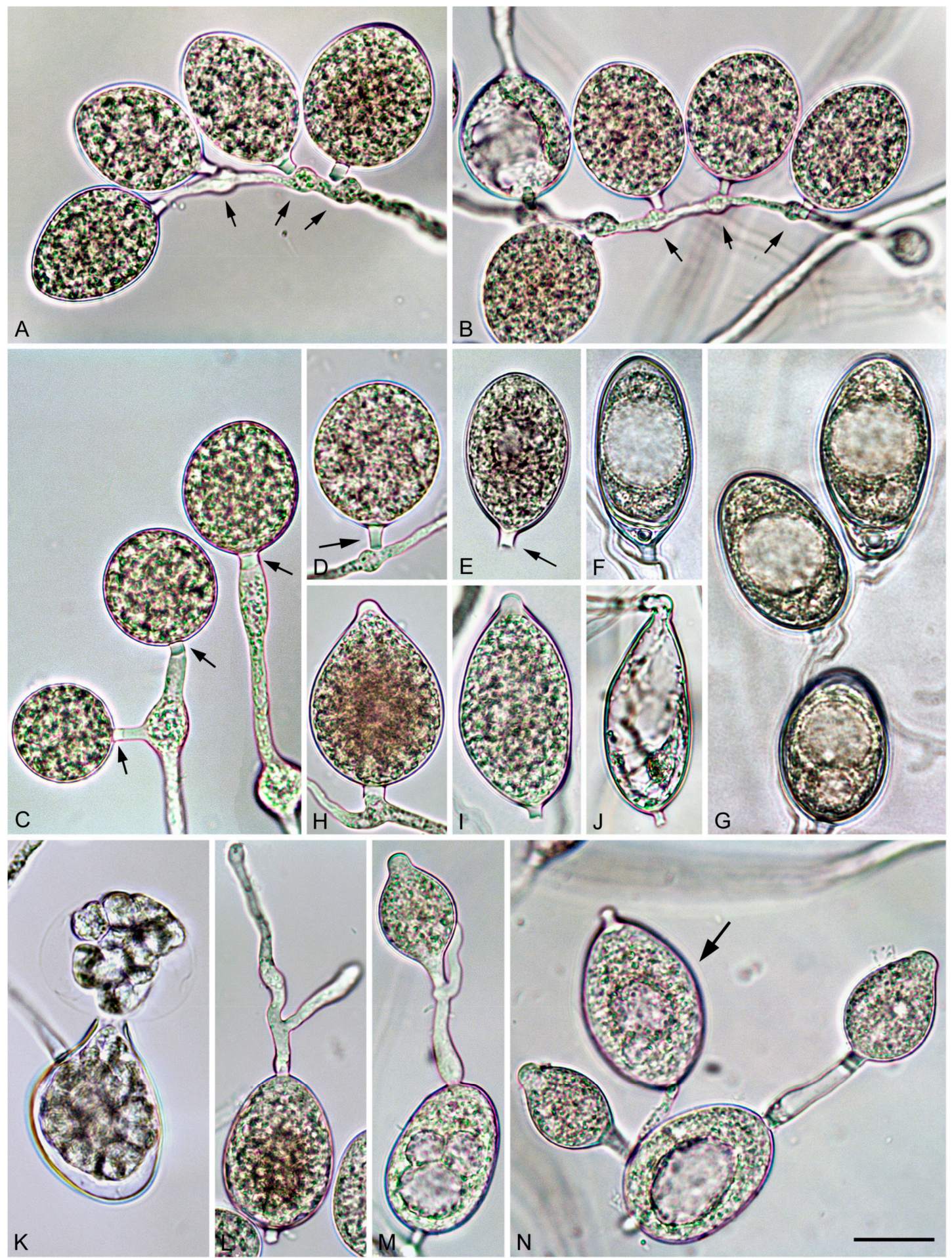

Figure 3. Pseudoconidia and sporangia of Phytophthora heterospora. (A,B) Ovoid pseudoconidia forming monochasial helicoid sympodia, still attached to the conidiophores or recently detached with nodose swellings (arrows) at the insertion points of the pseudoconidia to the conidiophores; (C) spherical to ovoid pseudoconidia with short pre-formed pedicels (arrows); (D,E) detached pseudoconidia with short pedicels (arrows); (F) ellipsoid conidium, with large lipid globule, tapering base, and external proliferation; (G) catenulate ellipsoid pseudoconidia with large lipid globules, forming a monochasial sympodium; (H) ovoid, laterally attached papillate sporangium; (I) limoniform papillate sporangium with short pedicel; (J) empty sporangium with direct germination through the apex; (K) sporangium releasing zoospores; (L-N) pseudoconidia germinating by forming papillate microsporangia and a new conidium (arrow). Scale bar: $25 \mu \mathrm{m}$. 

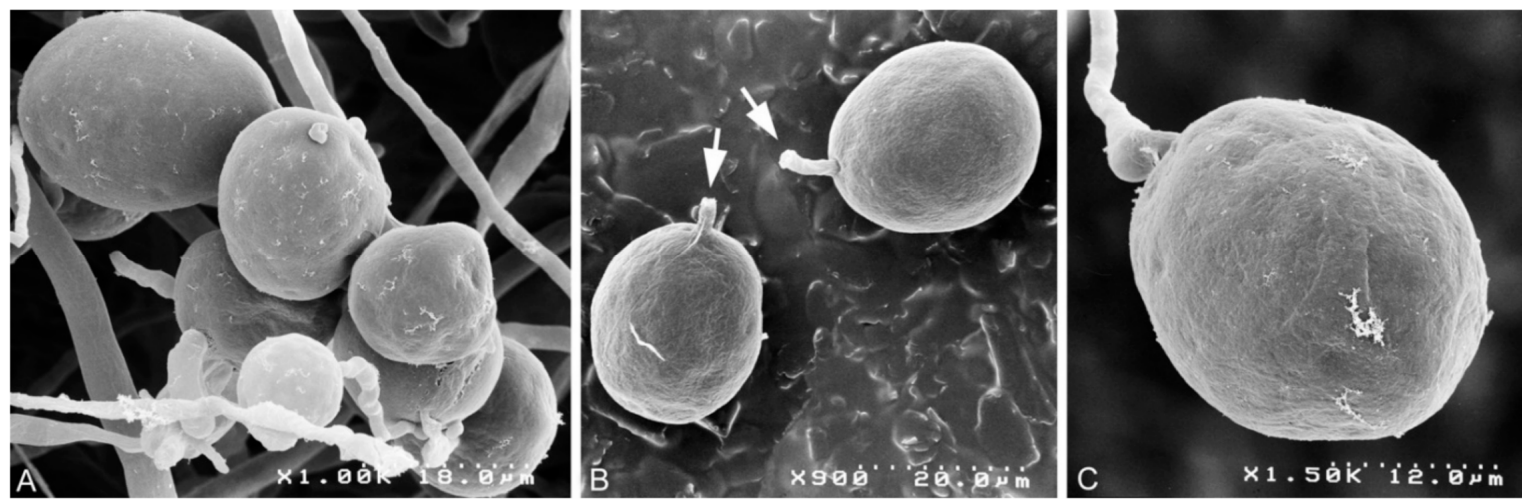

Figure 4. Scanning electron microscopy (SEM) images of pseudoconidia formed by Phytophthora heterospora on carrot agar: (A) cluster of pseudoconidia; (B) detached globose pseudoconidia with short pedicels (arrows); (C) ovoid pseudoconidium still attached to the conidiophore. Magnifications and scale bar dimensions are given in the right-bottom corners.

Description: pseudoconidia were abundantly produced in solid media (CA and V8A) but less frequently formed in non-sterile soil extract water (Figure 3A-G). Shapes of pseudoconidia showed a wide variation ranging from ellipsoid (over all isolates $76.4 \%$; Figure $3 \mathrm{~A}, \mathrm{~B}, \mathrm{E}-\mathrm{G})$ or subglobose to globose (14.8\%; Figure $3 \mathrm{C}, \mathrm{D})$ or ovoid $(6.8 \%$; Figure $3 \mathrm{C}, \mathrm{D})$ and limoniform $(2.0 \%)$, sometimes containing a large vacuole at maturity (Figure 3F,G). Pseudoconidia had mostly round or less frequently tapered bases, proliferating externally with hyphae arising close to the base and mainly forming monochasial helicoid sympodia (Figure 3A-C). Empty pseudoconidia were characterized by a thick wall. All pseudoconidia were caducous, showing a short pre-formed pedicel $<5 \mu \mathrm{m}$ (av. $3.9 \pm 0.4 \mu \mathrm{m})$, which breaks off from the bearing conidiophore (Figure 4B). Nodose swellings were common at the insertion points of the pseudoconidia to the conidiophore (Figure 3A-D). The pseudoconidia dimensions of the 10 isolates of $P$. heterospora averaged $34.7 \pm 1.8 \mu \mathrm{m}$ in length (l) and $27.1 \pm 1.1 \mu \mathrm{m}$ in breadth (b) (overall range 24.0-44.2 $\times 16.5-27.1 \mu \mathrm{m}$ ) with a $1 / \mathrm{b}$ ratio of $1.6 \pm 0.1$ (range of isolate means 1.3-1.7). Pseudoconidia did not release zoospores but germinated directly with one or more germ tubes, which usually emerged through the conidial wall and originated new pseudoconidia or papillate microsporangia (Figure 3L-N).

Sporangia of $P$. heterospora were readily produced in non-sterile soil extract water but were more rarely observed in solid agar (CA and V8A) (Figure 3H-J,L-N), typically borne terminally on unbranched sporangiophores or in irregular lax or regular dense sympodia. Sporangia often originated from a conidium (Figure $3 \mathrm{~L}-\mathrm{N}$ ) and proliferated externally (Figure $3 \mathrm{M}$ ). Sporangial shapes were diverse ranging from ovoid (overall isolates $68.4 \%$; Figure $3 \mathrm{H}, \mathrm{N})$ or elongate-ovoid to elongate-obpyriform (14.8\%; Figure $3 \mathrm{~J})$ or limoniform (6.8\%; Figure 3I,L-N), mouse to distorted shapes $(6.3 \%)$ and subglobose $(3.7 \%)$, often with laterally attached sporangiophore (48.6\%), occasionally with markedly curved apex $(8.6 \%)$ and presence of a vacuole $(8.0 \%$; Figure $3 \mathrm{I}, \mathrm{N})$ and rarely with a hyphal appendix. Sporangia were caducous, with a short pedicel $<5 \mu \mathrm{m}$ (av. $3.6 \pm 0.5 \mu \mathrm{m})$, papillate or very rarely bipapillate (overall isolates $<1 \%$ ). The sporangial dimensions averaged $42.8 \pm 5.9 \mu \mathrm{m}$ in length (1) and $24.7 \pm 3.5 \mu \mathrm{m}$ in breadth (b) (overall range 15.6-72.6 $\times 12.4-42.0 \mu \mathrm{m}$ ) with $\mathrm{a} 1 / \mathrm{b}$ ratio of $1.7 \pm 0.1$ (range of isolate means 1.4-1.9). Sporangia germinated directly by forming a germ tube (Figure 3J) that originated a new sporangium or indirectly by releasing zoospores (Figure 3K). Zoospores limoniform to reniform whilst motile, becoming spherical (av. diam $=8.8 \pm 1.2 \mu \mathrm{m}$ ) on encystment. The proportion of pseudoconidia vs. sporangia varied based on the isolate and cultural conditions, with two major groups behaving differently (Table 2). 

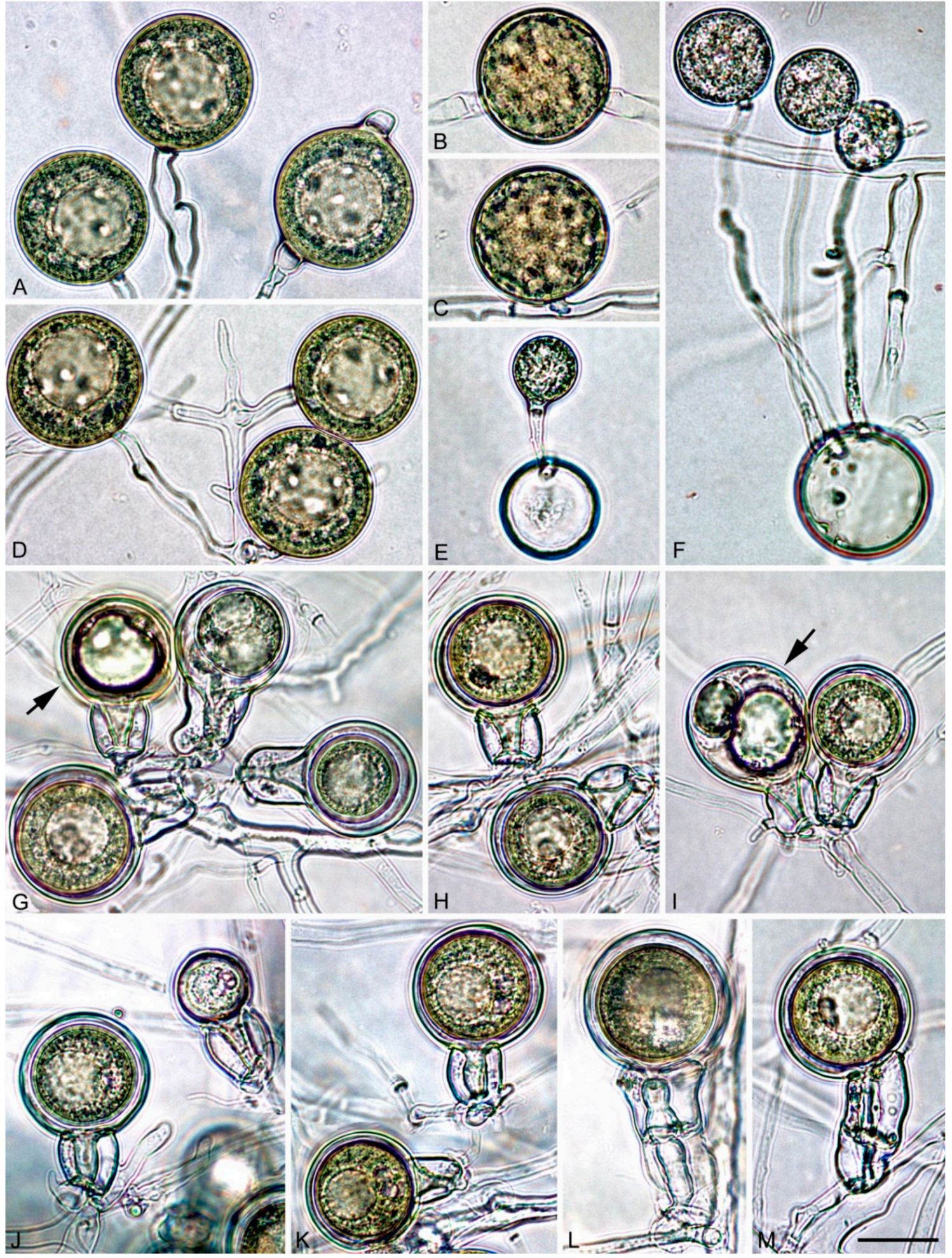

Figure 5. Chlamydospores and gametangia of Phytophthora heterospora. (A-F) Thick walled, globose chlamydospores; (A,D) terminal with lipid globules; (B) intercalary; (C) laterally attached chlamydospores; (E,F) germinating chlamydospores with one or more germ tubes forming new chlamydospores; (G-M) globose oogonia with aplerotic oospores containing large lipid globules and amphigynous antheridia; (G) oogonia with short tapering bases formed in a clump, one with aborted oospores (arrow); (I) oogonia with short tapering bases, one with aborted oospore and finger-like projection on the antheridium (arrow); (J,K) oogonia with short unicellular antheridia; (L) oogonia with very long bicellular antheridium; (M) comma-shaped oogonium with long bicellular antheridium. Scale bar: $25 \mu \mathrm{m}$. 
Table 2. Proportion (\%) of pseudoconidia, sporangia, and chlamydospores produced by Phytophthora heterospora, P. taxon palmivora-like and P. palmivora at $20^{\circ} \mathrm{C}$ on solid carrot agar (CA) and on CA submerged in nonsterile soil extract water.

\begin{tabular}{ccc}
\hline \multirow{2}{*}{ Phytophthora spp. } & \multicolumn{2}{c}{ Pseudoconidia/Sporangia/Chlamydospores } \\
\cline { 2 - 3 } & CA & Water \\
\hline P. heterospora $^{1}$ & $86 / 8 / 6$ & $74 / 24 / 2$ \\
P. heterospora $^{2}$ & $34 / 56 / 10$ & $26 / 74 / 8$ \\
P. taxon palmivora-like & $-/ 82 / 18$ & $-/ 85 / 15$ \\
P. palmivora & $-/ 78 / 22$ & $-/ 80 / 20$ \\
\hline
\end{tabular}

${ }^{1}$ Isolates from Capparis spinosa, Juniperus oxycedrus, and Olea europaea in Italy. ${ }^{2}$ Isolates from Durio zibethinus in Vietnam

Hyphal swellings were frequently occurring along the sporangiophores and conidiophores, subglobose to mostly globose, intercalary, catenulate averaging $10.4 \pm 3.6 \mu \mathrm{m}$. Diameters of primary hyphae ranged from 3.2 to $6.8 \mu \mathrm{m}$. Chlamydospores were abundantly produced on CA and V8A (Figure 5A-F); they were thick-walled, globose, and terminally (Figure 5A,D), intercalary (Figure 5B), or laterally (Figure 5C) inserted, with $28.4 \pm 4.4 \mu \mathrm{m}$ diameter (overall range 19.3-43.0 $\mu \mathrm{m}$ ). Chlamydospores often germinated with one or more germ tubes originating new smaller chlamydospores (Figure $5 \mathrm{E}, \mathrm{F}$ ).

All $P$. heterospora isolates were self-sterile and produced gametangia readily when paired with A2 isolates of $P$. palmivora using the polycarbonate membrane test on CA (Figure $5 \mathrm{~K}-\mathrm{N}$ ). No gametangia were produced when isolates of $P$. heterospora were paired with each other or with A1 mating-type tester strains of $P$. cinnamomi. Oogonia were globose, sometimes slightly comma-shaped (Figure $5 \mathrm{M}$ ), often with short tapering bases (av. 74.6\%; Figure 5G-K), or elongated with long and often distorted bases (av. 25.4\%; Figure 5L,M), produced in pairs or clumps (Figure 5G-I) or single and borne laterally (Figure 5J-M). Oogonial walls were always smooth and occasionally turned golden-brown within 4 weeks (Figure 5G,H). Oogonial diameters averaged $30.5 \pm 2.2 \mu \mathrm{m}$, with a total range of 24.3-37.4 $\mu \mathrm{m}$. Oospores were aplerotic (av. 94.7\%; Figure 5G,L,M) or infrequently plerotic (av. 5.3\%; Figure 5H-K), contained large ooplasts, occasionally excentric, with thin walls (on av. $1.6 \pm 0.3 \mu \mathrm{m}$ ) and a mean oospore wall index of $0.33 \pm 0.06$. Oospore abortion rates averaged $60 \%$ (Figure 5G,I). Antheridia were exclusively amphigynous, $51.4 \%$ unicellular (Figure 5G-K), and $48.6 \%$ bicellular (Figure 5L,M), averaging $15.3 \pm 2.8 \mu \mathrm{m}$ in length and $13.8 \pm 1.5 \mu \mathrm{m}$ in breadth, with a $1 / \mathrm{b}$ ratio of $1.1 \pm 0.1$, often with one or more finger-like projections.

Colony morphology and growth rates: $P$. heterospora colonies were radiate with limited aerial mycelium on CA and V8A, uniform and slightly woolly on PDA and poorly developed, dense-felty with irregular margin on MEA (Figure 6). Temperature-growth relations are shown in Figure 7A. All eight isolates included in the growth test had similar growth rates. The maximum growth temperature was around $32.5^{\circ} \mathrm{C}$, while the minimum temperature was above $10^{\circ} \mathrm{C}$. The average radial growth rate at the optimum temperature of $27.5^{\circ} \mathrm{C}$ was $12.8 \mathrm{~mm} / \mathrm{d}$ (Figure $7 \mathrm{~A}$ ).

Other specimens examined (paratypes): Italy, Sardinia, Villamar. Isolated from a collar lesion of a young Olea europaea tree. Collected by: B. Scanu, 2010; CBS H-24778, CBS 148035 = PH051. Sardinia, Villamar. Isolated from rhizosphere soil of Olea europaea saplings. Collected by: B. Scanu, 2010; PH052; PH057. Sardinia, Sorso. Isolated from rhizosphere soil of a young Olea europaea trees. Collected by: B. Scanu, 2010; PH047. Italy, Sicily, Catania. Isolated from Capparis spinosa. Collected by: S.O. Cacciola, 2014; CBS H24779, CBS 148036 = 317-A12. Italy, Calabria, Lamezia Terme. Isolated from Olea europaea . Collected by: S.O. Cacciola, 1999; Palm2. Italy, Sicily, Campobello di Mazara. Isolated from Olea europea. Collected by: S.O. Cacciola, 2005; Campobello 2b. Vietnam, Mekong Delta, Vinh Long. Isolated from necrotic bark lesions on Durio zibethinus trees. Collected by: S.O. Cacciola, 2013; DB2; A1A; A1B1; C2B1. 


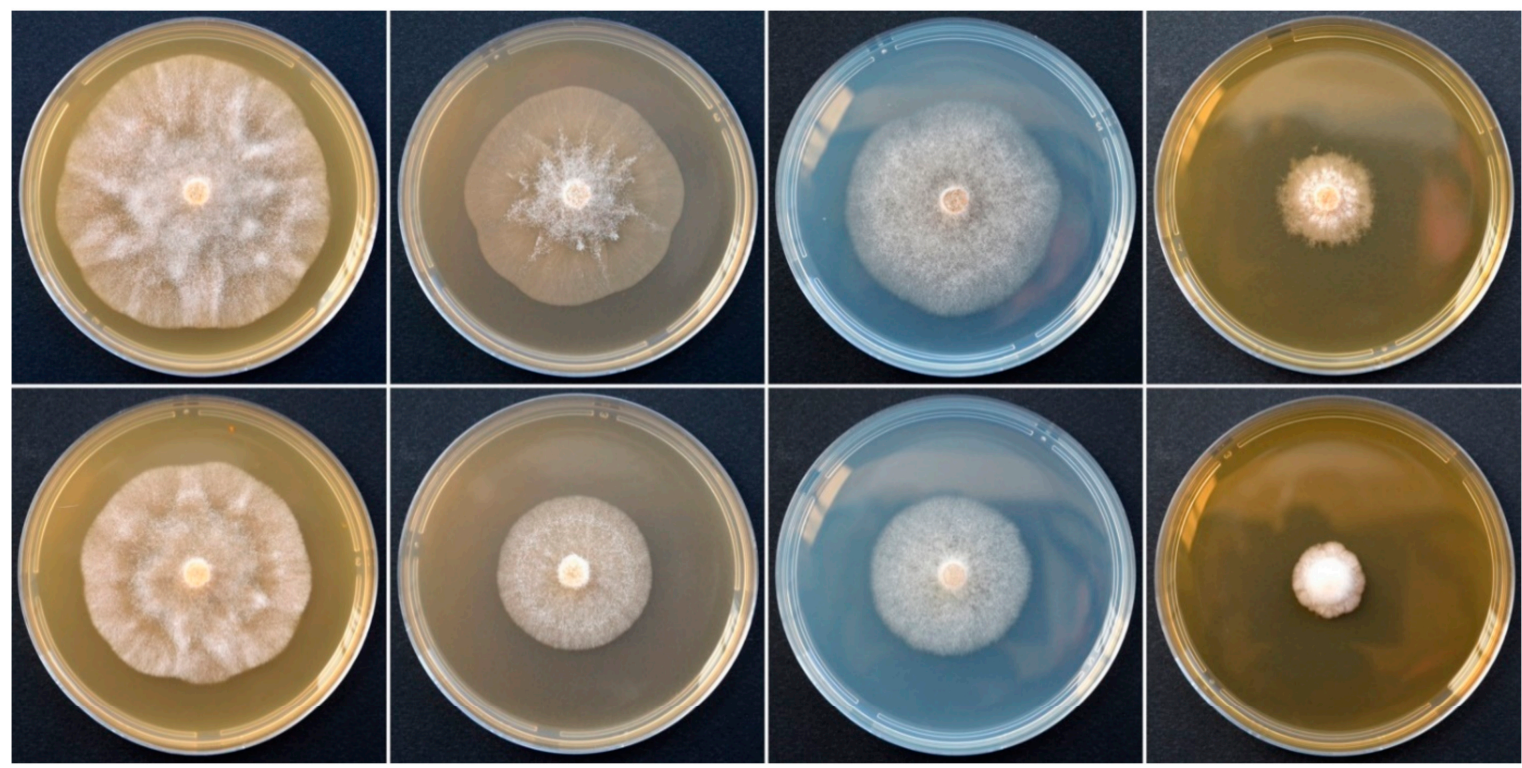

Figure 6. Colony morphologies of Phytophthora heterospora (upper row; isolate PH054) and P. palmivora (bottom row; isolate CBS 179.26) after 4 days growth at $20^{\circ} \mathrm{C}$ in the dark on CA, V8A, PDA, and MEA (from left to right).

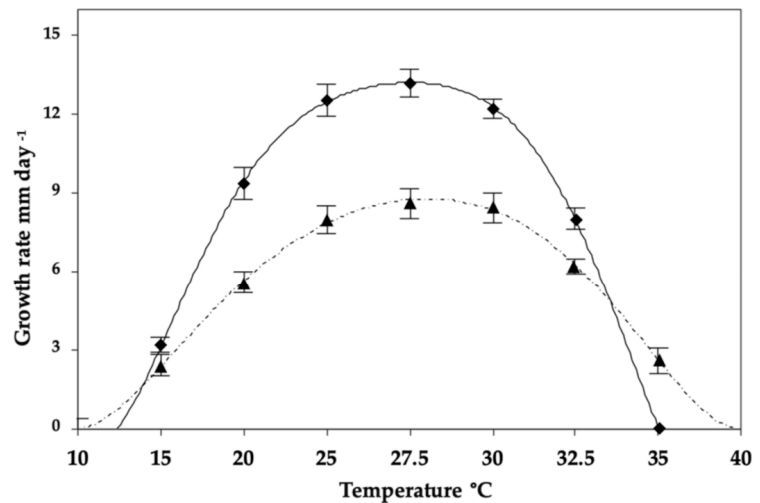

(A)

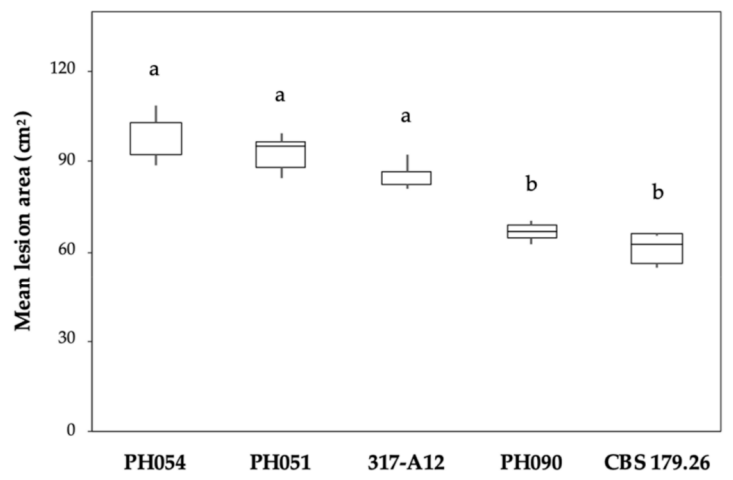

(B)

Figure 7. Temperature-growth relations and pathogenicity of Phytophthora taxa: (A) radial growth rates of $P$. heterospora (continuous line; 10 isolates) and P. palmivora (dashed line; 4 isolates) on CA at different temperatures. The data are plotted as average $\mathrm{XD}$; (B) box and whiskers diagram showing mean lesion areas produced by three isolates of $P$. heterospora (PH054, PH051, and 317-A12), P. taxon palmivora-like (PH090), and P. palmivora (CBS 179.26) on 2-year-old olive saplings after 2 months. Control saplings did not show any necrotic lesions around the inoculation points and were not included. Different letters above bars indicate significant differences according to Fisher's LSD test $(p=0.05)$.

Host/distribution: Olea europaea, Juniperus oxycedrus, and Capparis spinosa (Italy); Ziziphus spina-christi (Iran) and Durio zibethinus (Vietnam).

Notes: Phytophthora heterospora and P. palmivora are very similar in terms of colony morphology and sporangia, chlamydospores, and gametangia characteristics. However, $P$. heterospora can be easily distinguished by the production of pseudoconidia on solid agar media. Other key differences between P. heterospora and P. palmivora are (i) the lower maximum temperature for growth and faster growth rates at most temperatures of $P$. heterospora, and (ii) the higher oospore abortion rate of $P$. heterospora (60\% vs. $48 \%$ ). Phylogenetically, P. heterospora differs from P. palmivora in ITS, Btub, cox 1 , and nadh1 by $3-4,11-16,1-2$, and 6 fixed polymorphisms, respectively. Although P. heterospora is present on four continents, its geographic distribution presently seems to be restricted to a few countries and mainly to nursery plants and new plantations, contrasting with the global 
distribution of P. palmivora in a wide range of natural, horticultural, and ornamental ecosystems and nurseries [1,18,39].

\subsection{Pathogenicity}

In the inoculation tests, both P. heterospora and P. palmivora were shown to be pathogenic to O. europaea (Figure 7B). All isolates used in the experiments were able to cause necrotic lesions significantly larger $(p<0.0001)$ than those of the negative controls. Overall, with mean lesion areas of $92.4 \pm 8.2$, P. heterospora was significantly $(p<0.05)$ more aggressive than P. palmivora, with $64.1 \pm 5.2 \mathrm{~cm}^{2}$. The isolate PH054 was the most aggressive among the $P$. heterospora isolates, causing a mean lesion area of $98.2 \pm 8.2$, but intraspecific differences were statistically not significant $(p>0.05)$. Saplings inoculated with Phytophthora species developed the typical symptoms observed in the field, such as leaf chlorosis, wilting, and defoliation. Phytophthora taxon palmivora-like (PH090) were also pathogenic with necrotic lesions comparable with P. palmivora. All Phytophthora taxa were re-isolated from necrotic stem lesions.

On durian branches wound-inoculated with the Vietnamese P. heterospora isolate DB2 from durian, the first symptoms, consisting of gum exudation and bark necrosis, appeared 15 days after inoculation. After 30 days, the mean area of necrotic lesions in inoculated branches was $96 \pm 10 \mathrm{~mm}^{2}$. No symptoms were observed on the control branches.

\section{Discussion}

Species in the genus Phytophthora are characterized by the production of asexual sporangia releasing biflagellate zoospores into an evanescent vesicle that soon breaks, allowing zoospores to swim into the water [1]. The occurrence of an additional asexual dissemination structure in P. heterospora, designated here as pseudoconidium, which germinates directly instead of releasing zoospores, represents a unique feature of the genus Phytophthora. This trait, referred to as sporocyst, was previously reported by Babacauh in 1983 on isolates obtained from T. cacao in the Ivory Coast, designated as P. palmivora var. heterocystica because of the differentiation of unusual conidia-like sporangia $[1,14]$. Since no specimens or DNA sequence data linked to the original description are available and no further reports of this variety have been published, it remains unclear whether $P$. heterospora and P. palmivora var. heterocystica belong to the same taxon, although it cannot be ruled out.

As stated by Babacauh [1,14], the occurrence of pseudoconidia may be an evolutionary trend towards less dependence on free water, as shown for various downy mildew groups. Similar transitional phenotypic and ecological characters between the hemibiotrophic or necrotrophic Phytophthoras and the obligate biotrophic downy mildews have been reported in other species and genera $[1,40,41]$. This is the case with Phytophthora litchii, the taxonomic position of which has long been controversial due to the differentiation of Peronospora-like sporangiophores [42,43], and all the unculturable obligate biotrophic Phytophthora species, including P. cyperi, P. leersiae, P. lepironiae, and P. polygoni $[4,44,45]$. Other examples include the genera Viennotia, Poakatesthia, and Sclerophthora, which possess similar features to Phytophthora species, although they are placed among the downy mildews [46-48]. In 1952, Gäumann [49] had proposed that Phytophthora spp. and downy mildews were likely to be related, but their taxonomic relationship has long been a matter of debate [50,51]. The first phylogenetic studies using nuclear ITS rDNA suggested that the two taxonomic groups potentially form a monophyletic clade [22,52]. This hypothesis was corroborated by subsequent multigene phylogenetic and phylogenomic studies, with all downy mildews unambiguously residing within the genus Phytophthora $[4,40,41,53-55]$. Similar results were obtained in the phylogenetic analyses of the present study using a concatenated nuclear and mitochondrial 4-locus dataset. Downy mildews were nested within the Phytophthora clades. As shown before by Bourret et al. [4], in addition to Phytophthora clades 1-12 and 14, two further clades were identified, one accommodating the DMCC, GDM, and BDM and another one the DMPH. Clade 13 currently consists exclusively of the 
undescribed Phytophthora taxon mugwort [4]. Apparently, in the genus Phytophthora, an obligate biotrophic lifestyle evolved independently several times since the DMCC, GDM, and BDM share a common ancestor with Phytophthora clades 1-5, 12 and 14, whereas the $\mathrm{DMPH}$, together with the obligate biotrophic P. cyperi from clade 14, share a common ancestor with Phytophthora clade 1. No close phylogenetic relationship was found between P. heterospora and any of the downy mildews included in the analyses, although in previous phylogenetic studies using only single genes, clade 4 species were several times shown to be the nearest relatives to the downy mildews $[4,22,43]$. However, as reported for the downy mildew-like species $P$. litchii (also clade 4 ), P. heterospora may share some genomic characteristics with the downy mildews forced by environmental and host adaptation during its evolution [43].

Phylogenetically, P. heterospora is closely related to P. palmivora, from which it can be distinguished by 3-4 fixed polymorphisms in ITS sequences and a total of $18-25 \mathrm{bp}$ differences across the $B t u b, c o x 1$, and nadh1 gene regions. Nonetheless, due to the high intraspecific variability ([18], this study) and the lack of any type material or key specimens for P. palmivora [56,57] that could serve as DNA sources for robust molecular identification and phylogenetic studies, isolates belonging to $P$. heterospora have often been misidentified in the past. A search of ITS sequences in the National Center for Biotechnology Information (NCBI) database and previous publications revealed that isolates with sequences identical to $P$. heterospora have been recorded from almost all continents and different hosts. The crown and root rot of pomegranate reported in young plantations in Italy and Turkey appear to be most likely caused by $P$. heterospora $[58,59]$. The lower maximum temperature $\left(<35^{\circ} \mathrm{C}\right)$ for mycelium growth of Turkish isolates and their phylogenetic position indicate that they did not belong to P. palmivora [59]. Similarly, the dieback and mortality of young olive trees in a nursery and in plantations in Souk El Arbaa (Morocco) attributed to $P$. palmivora [60] were presumably also caused by $P$. heterospora, as demonstrated by the occurrence of subglobose and non-papillate sporangia, which resemble pseudoconidia. Unfortunately, the identification of the isolates was based exclusively on morphological characteristics, and no DNA sequences are available [60]. All these records, together with the finding of $P$. heterospora from olive plantations in this study, suggest that the pathogen is well-established in agricultural tree crops in areas with Mediterranean and semi-arid climatic conditions, most likely favored by the intensive cultivation systems [61,62]. The clonal nature and high virulence of $P$. heterospora, as well as its restricted distribution to nurseries and new plantings, indicate that it is an emerging and potentially invasive pathogen recently introduced via infected plants $[63,64]$. This hypothesis is supported by the abundant detection of $P$. heterospora in asymptomatic potted plants of ten different hosts in two large European retail nurseries using a qPCR technique [65].

The current distribution of $P$. heterospora in the field, however, may be limited by hot temperatures and drought in summer, which are not favorable to the requirements of the pathogen for growth and sporulation. Similar to its closest relative, P. palmivora, P. heterospora might also be more adapted to an aerial lifestyle, requiring high humidity $[39,66]$, as revealed by the findings from durian trees in tropical Southeast Asia, including Indonesia, Malaysia, Thailand, and Vietnam (this study). The morphological and physiological attributes of $P$. heterospora support its ability to behave either as an aerial or soilborne pathogen. The production of caducous pseudoconidia, in addition to the caducous sporangia, provides $P$. heterospora with an ecological advantage in durian farms in southern Vietnam, as during monsoon season pseudoconidia are spread aerially by rain and wind and may infect stems and branches. During the dry season, water splashes caused by sprinkler irrigation systems may also favor aerial infections $[39,66]$. The ability to cause cankers on fruit-bearing trees of durian suggests that P. heterospora may be an aggressive pathogen, provided that environmental conditions are conducive, i.e., in tropical and subtropical regions. In addition, some key morphological properties, such as a heterothallic breeding system, an oospore wall index of only 0.33 , caducity of pseudoconidia and sporangia, and thick-walled chlamydospores, indicate a potential center of origin of $P$. heterospora in 
tropical regions, most likely Southeast Asia, Central America, or West Africa, as suggested for most clade 4 species $[67,68]$. The finding of an isolate with identical ITS sequence to P. heterospora (GenBank accession: KY475630) from T. cacao in Ghana, a neighbor country to the Ivory Coast, where P. palmivora var. heterocystica was originally described, supports the hypothesis of a West African origin [1,14]. However, to ascertain the evolutionary and geographic origin of $P$. heterospora, further studies are needed, including surveys in yet non-surveyed natural environments to detect the pathogen on co-evolved hosts without causing diseases $[69,70]$, followed by phenotyping and genotyping studies using a global population [71-73].

The differences in the proportion of pseudoconidia and sporangia production recorded (1) for the same $P$. heterospora isolates between solid dry agar and water culture and (2) between $P$. heterospora isolates from Mediterranean regions in Italy and humid tropical Vietnam are of high interest. The ability of P. heterospora to partially switch between asexual structures depending on the substrate of growth, i.e., increase in pseudoconidia production on solid agar and sporangia production in water, respectively, indicates that this trait evolved as an adaptation to specific environmental conditions [18]. Therefore, isolates of P. heterospora from Mediterranean and semi-arid regions may be on the evolutionary path towards a lifestyle as a conidial plant pathogen with reduced dependence on free water, while isolates from Vietnam apparently prefer sporangia due to the conducive conditions in humid tropical environments [39]. Spore formation and germination involve the staged expression of a large subset of the transcriptome, commensurate with the importance of spores in the life cycle. Therefore, further studies using new technologies such as RNAseq may be effective in understanding spore biology and the pathogenic mechanisms of P. heterospora [74].

Remarkably, isolates PH083 and PH090 from A. unedo in Italy belonged to a discreet lineage in an intermediate evolutionary position between $P$. heterospora and $P$. palmivora and, consequently, were designated as $P$. taxon palmivora-like. Both nuclear gene sequences and the absence of pseudoconidia characterize these isolates as P. palmivora. However, their $\operatorname{cox} 1$ and $n a d h 1$ sequences are identical to P. heterospora, i.e., they share the same maternal line. This feature was previously reported for the three hybrid species in clade $7 \mathrm{a}-$ namely, P. $\times$ cambivora, $P . \times$ heterohybrida, and $P . \times$ incrassat $a$, which share the same nadh 1 genotype and, hence, most likely the same maternal parent [75]. Interestingly, the occurrence of multiple heterozygous sites in the Btub sequences of both $P$. taxon palmivora-like (7) and P. palmivora (10) suggests that they may originate from sexual hybridization rather than somatic fusion, a feature common to all known Phytophthora hybrids [76,77]. However, further molecular analyses, such as cloning, sequencing of other nuclear and mitochondrial genes, and estimation of nuclear DNA content and ploidy level by flow cytometry, are required to confirm this hypothesis [75].

Our finding of high phenotypic and genetic variability amongst $P$. palmivora isolates is in accordance with previous studies $[18,67,78]$. The two isolates from jackfruit in Vietnam [21] were genetically different from all the other P. palmivora isolates. Interestingly, they originate from the same area of the Mekong River Delta as the P. heterospora isolates from durian trees [21]. Further investigations are urgently needed to characterize the global population structure of $P$. palmivora, considering its panglobal distribution and high impact on a wide range of horticultural and ornamental plant species, as well as on natural wild ecosystems [39].

\section{Conclusions}

Our study demonstrates that the Phytophthora isolates from olive trees in Italy, characterized by the unique ability to produce pseudoconidia, belong to a new species described here as $P$. heterospora sp. nov. Italy is one of the leading olive producers, with more than one million hectares, accounting for about $10 \%$ of the world's cultivation area [79]. The severity of symptoms observed on infected trees, together with the results from pathogenicity tests, indicate that the pathogen could represent a new emerging threat to olive cultivation, 
particularly in newly established plantations, where pathogen infection appears to be favored by agronomic practices and recurrent water irrigation. Over the last few years, an increasing number of Phytophthora species have been associated with a decline in olive trees in Mediterranean regions [80-84].

Likewise, the impact of $P$. heterospora on durian production in Vietnam may be underestimated. The durian industry in Vietnam is small but rapidly expanding, catering mainly for the domestic market, with some export trade with Taiwan [39]. In many cases $P$. heterospora may have been misidentified as P. palmivora, and previous reports of P. palmivora as a pathogen of durian in Vietnam should be reconsidered if they were not supported by phylogenetic analysis.

Finally, nurseries provide an environment where P. heterospora is widespread in Italy, Iran, and Vietnam, mainly as a soilborne pathogen infecting fine roots of several hosts, including agricultural tree crops and forest species. This highlights, once again, the primary role of nurseries in spreading Phytophthora pathogens with uncertified plant material into new ecosystems $[63,64]$.

Supplementary Materials: The following are available online at https:/ /www.mdpi.com/article/10 .3390/jof7100870/s1, Table S1: Information of all oomycete isolates used in the phylogenetic analyses, including local, international, and alternative isolate identifications, Table S2: Base pairs differences across Btub, ITS, Cox1, nadh1 sequences showing inter- and intraspecific variation of Phytophthora heterospora, P. palmivora, and P. taxon palmivora-like.

Author Contributions: Conceptualization, B.S., T.J., B.T.L. and S.O.C.; methodology, B.S. and T.J.; formal analysis, B.S., T.J., H.M., B.T.L., M.H.J., A.B. and J.J.; investigation, B.S., T.J., H.M., B.T.L., M.R. and S.O.C.; data curation, B.S. and S.O.C.; writing-original draft preparation, B.S., T.J. and S.O.C.; writing-review and editing, B.S., T.J., H.M., B.T.L., M.H.J., A.B., R.M.-G., J.J., M.R. and S.O.C.; funding acquisition, B.S., T.J. and S.O.C. All authors have read and agreed to the published version of the manuscript.

Funding: This study was supported by the "fondo di Ateneo per la ricerca 2019", an internal funding provided by the University of Sassari. This research was funded by the University of Catania, Italy, "Investigation of phytopathological problems of the main Sicilian productive contexts and eco-sustainable defense strategies (MEDIT-ECO)" "PiaCeRi-PIAno di inCEntivi per la Ricerca di Ateneo 2020-22 linea 2" "5A722192155". The study was also co-funded by the Project Phytophthora Research Centre Reg. No. CZ.02.1.01/0.0/0.0/15_003/0000453, financed by the Czech Ministry for Education, Youth and Sports and the European Regional Development Fund.

Data Availability Statement: All sequences generated during this study are available from GenBank and accession numbers are given in Table S1. All datasets and trees derived from BI and ML analyses are available from DRYAD (https:/ / datadryad.org) (Dryad Dataset, https://doi.org/10.5061/dryad. 1jwstqjvx).

Acknowledgments: M.R. was granted a fellowship by CREA "OFA" (Rende, Italy), and this study is part of his activity as PhD, in "Agricultural, Food, and Forestry Science", University Mediterranea of Reggio Calabria, XXXV cycle".

Conflicts of Interest: The authors declare no conflict of interest.

\section{References}

1. Erwin, D.C.; Ribeiro, O.K. Phytophthora Diseases Worldwide; APS Press American Phytopathological Society: St. Paul, MN, USA, 1996; p. 562.

2. Hansen, E.M.; Reeser, P.W.; Sutton, W. Phytophthora beyond agriculture. Ann. Rev. Phytopathol. 2012, 50, 359-378. [CrossRef]

3. Jung, T.; Sierra-Perez, A.; Duran, A.; Horta Jung, M.; Balci, Y.; Scanu, B. Canker and decline diseases caused by soil- and airborne Phytophthora species in forests and woodlands. Persoonia 2018, 40, 182-220. [CrossRef]

4. Bourret, T.B.; Choudhury, R.A.; Mehl, H.K.; Blomquist, C.L.; McRoberts, N.; Rizzo, D.M. Multiple origins of downy mildews and mito-nuclear discordance within the paraphyletic genus Phytophthora. PLoS ONE 2018, 13, e0192502. [CrossRef] [PubMed]

5. Garbelotto, M.; Frankel, S.; Scanu, B. Soil-and waterborne Phytophthora species linked to recent outbreaks in Northern California restoration sites. Calif. Agric. 2018, 72, 208-216. [CrossRef] 
6. Jung, T.; Horta Jung, M.; Cacciola, S.O.; Cech, T.; Bakonyi, J.; Seress, D.; Mosca, S.; Schena, L.; Seddaiu, S.; Pane, A.; et al. Multiple new cryptic pathogenic Phytophthora species from Fagaceae forests in Austria, Italy and Portugal. IMA Fungus 2017, 8, $219-244$. [CrossRef] [PubMed]

7. Oßwald, W.; Fleischmann, F.; Rigling, D.; Coelho, A.C.; Cravador, A.; Diez, J.; Dalio, R.J.; Horta Jung, M.; Pfanz, H.; Robin, C.; et al. Strategies of attack and defence in woody plant-Phytophthora interactions. For. Pathol. 2014, 44, 169-190. [CrossRef]

8. Bassani, I.; Larousse, M.; Tran, Q.D.; Attard, A.; Galiana, E. Phytophthora zoospores: From perception of environmental signals to inoculum formation on the host-root surface. Comput. Struct. Biotechnol. J. 2020, 18, 3766-3773. [CrossRef] [PubMed]

9. Harris, A.R.; Webber, J.F. Sporulation potential, symptom expression and detection of Phytophthora ramorum on larch needles and other foliar hosts. Plant Pathol. 2016, 65, 1441-1451. [CrossRef]

10. Scanu, B.; Webber, J.F. Dieback and mortality of Nothofagus in Britain: Ecology, pathogenicity and sporulation potential of the causal agent Phytophthora pseudosyringae. Plant Pathol. 2016, 65, 26-36. [CrossRef]

11. Scanu, B.; Cacciola, S.O.; Linaldeddu, B.; Pane, A.; Franceschini, A.; Magnano di San Lio, G. Characterization and evolutionary significance of a new Phytophthora species producing conidia. J. Plant Pathol. 2015, 97, 38.

12. Cacciola, S.O.; Agosteo, G.E.; Pane, A. First report of Phytophthora palmivora as a pathogen of olive in Italy. Plant Dis. 2000, 84, 1153. [CrossRef] [PubMed]

13. Agosteo, G.E.; Magnano di San Lio, G.; Cacciola, S.O. Root rot of young olive trees caused by Phytophthora palmivora in southern Italy. Acta Hortic. 2002, 586, 709-712. [CrossRef]

14. Babacauh, K.D. Structure des populations de Phytophthora palmivora (Butl.) Butl. Emend. Bras. Et Griff. Parasite du cacaoyer (Theobroma cacao L.) (Population structure Phytophthora palmivora from cacao [Theobroma cacao L.]). Bul. Soc. Bot. Fr. Lett. Bot. 1983, $130,15-25$.

15. Scanu, B.; Hunter, G.C.; Linaldeddu, B.T.; Franceschini, A.; Maddau, L.; Jung, T.; Denman, S. A taxonomic re-evaluation reveals that Phytophthora cinnamomi and Pcinnamomi var. parvispora are separate species. For. Pathol. 2014, 44, 1-20.

16. Jung, T.; Blaschke, H.; Neumann, P. Isolation, identification and pathogenicity of Phytophthora species from declining oak stands. Eur. J. For. Path. 1996, 26, 253-272. [CrossRef]

17. Jeffers, S.N.; Martin, S.B. Comparison of two media selective for Phytophthora and Pythium spp. Plant Dis. 1986, 70, 1038-1043. [CrossRef]

18. Brasier, C.M.; Griffin, M.J. Taxonomy of Phytophthora palmivora on cocoa. T. Brit. Mycol. Soc. 1979, 71, 111-143. [CrossRef]

19. Pane, A.; Allatta, C.; Sammarco, G.; Cacciola, S.O. First report of bud rot of Canary Island date palm caused by Phytophthora palmivora in Italy. Plant Dis. 2007, 91, 1059. [CrossRef]

20. Cacciola, S.O.; Pennisi, A.M.; Agosteo, G.E.; Magnano di San Lio, G. First Report of Phytophthora palmivora on Grevillea spp. in Italy. Plant Dis. 2003, 87, 1006. [CrossRef]

21. Van Tri, M.; Van Hoa, N.; Minh Chau, N.; Pane, A.; Faedda, R.; De Patrizio, A.; Schena, L.; Olsson, C.H.B.; Wright, S.A.I.; Ramstedt, M.; et al. Decline of jackfruit (Artocarpus heterophyllus) incited by Phytophthora palmivora in Vietnam. Phytopathol. Mediterr. 2015, 54, 275-280.

22. Cooke, D.E.L.; Drenth, A.; Duncan, J.M.; Wagels, G.; Brasier, C.M. A molecular phylogeny of Phytophthora and related oomycetes. Fungal Genet. Biol. 2000, 30, 17-32. [CrossRef] [PubMed]

23. White, T.J.; Bruns, T.; Lee, S.; Taylor, J. Amplification and direct sequencing of fungal ribosomal DNA for phylogenetics. In PCR Protocols: A Guide to Methods and Applications; Innis, M.A., Gelfand, D.H., Sninsky, J.J., White, T.J., Eds.; Academic Press: San Diego, CA, USA, 1990; pp. 315-322.

24. Blair, J.E.; Coffey, M.D.; Park, S.-Y.; Greiser, D.M.; Kang, S. A multi-locus phylogeny for Phytophthora utilizing markers derived from complete genome sequences. Fungal Genet. Biol. 2008, 45, 266-277. [CrossRef] [PubMed]

25. Martin, F.N.; Tooley, P.W. Phylogenetic relationships among Phytophthora species inferred from sequence analysis of mitochondrially encoded cytochrome oxidase I and II genes. Mycologia 2003, 95, 269-284. [CrossRef] [PubMed]

26. Kroon, L.P.N.M.; Bakker, F.T.; van den Bosch, G.B.M.; Bonants, P.J.M.; Flier, W.G. Phylogenetic analysis of Phytophthora species based on mitochondrial and nuclear DNA sequences. Fungal Genet. Biol. 2004, 41, 766-782. [CrossRef]

27. Hall, T. BioEdit Version 5.0.6. Department of Microbiology, North Carolina State University. Available online: http:/ / www.mbio. ncsu.edu/BioEdit/bioedit.html (accessed on 8 June 2021).

28. O'Hanlon, R.; Destefanis, M.; Milenković, I.; Tomšovský, M.; Janoušek, J.; Bellgard, S.E.; Weir, B.S.; Kudláček, T.; Horta Jung, M.; Jung, T. Two new Nothophytophthora species from streams in Ireland and Northern Ireland: Nothophytophthora irlandica and N. lirii sp. nov. PLoS ONE 2021, 16, e0250527. [CrossRef]

29. Katoh, K.; Standley, D.M. MAFFT multiple sequence alignment software version 7: Improvements in performance and usability. Mol. Biol. Evol. 2013, 30, 772-780. [CrossRef] [PubMed]

30. Choi, Y.J.; Klosterman, S.J.; Kummer, V.; Voglmayr, H.; Shin, H.D.; Thines, M. Multi-locus tree and species tree approaches toward resolving a complex clade of downy mildews (Straminipila, Oomycota), including pathogens of beet and spinach. Mol. Phylogenet. Evol. 2015, 86, 24-34. [CrossRef]

31. Huelsenbeck, J.P.; Ronquist, F. MrBayes: Bayesian inference of phylogeny. Bioinformatics 2001, 17, 754-755. [CrossRef]

32. Ronquist, F.; Heuelsenbeck, J.P. MrBayes 3: Bayesian phylogenetic inference under mixed models. Bioinformatics 2003, 19, 1572-1574. [CrossRef] 
33. Edler, D.; Klein, J.; Antonelli, A.; Silvestro, D. raxmlGUI 2.0: A graphical interface and toolkit for phylogenetic analyses using RAxML. Methods Ecol Evol. 2020, 12, 373-377. [CrossRef]

34. Stamatakis, A. RAxML version 8: A tool for phylogenetic analysis and post-analysis of large phylogenies. Bioinformatics 2014, 30, 1312-1313. [CrossRef] [PubMed]

35. Maddison, W.P.; Maddison, D.R. Mesquite: A Modular System for Evolutionary Analysis. 2019 Version 3.61. Available online: http:/ / www.mesquiteproject.org (accessed on 1 June 2021).

36. Kumar, S.; Stecher, G.; Li, M.; Knyaz, C.; Tamura, K. MEGA X: Molecular evolutionary genetics analysis across computing platforms. Mol. Biol. Evol. 2018, 35, 1547-1549. [CrossRef]

37. Scanu, B.; Linaldeddu, B.T.; Deidda, A.; Jung, T. Diversity of Phytophthora species from declining Mediterranean maquis vegetation, including two new species, Phytophthora crassamura and P. ornamentata sp. nov. PLoS ONE 2015, 10, e0143234. [CrossRef]

38. Dick, M.W. Keys to Pythium; University of Reading Press: London, UK, 1990; p. 63.

39. Drenth, A.; Guest, D.I. Diversity and Management of Phytophthora in Southeast Asia; ACIAR Monograph 114; Australian Centre for International Agricultural Research: Canberra, Australia, 2004; p. 238.

40. Göker, M.; Voglmayr, H.; Riethmüller, A.; Oberwinkler, F. How do obligate parasites evolve? A multi-gene phylogenetic analysis of downy mildews. Fungal Genet. Biol. 2007, 44, 105-122. [PubMed]

41. Thines, M.; Choi, Y.J. Evolution, diversity, and taxonomy of the Peronosporaceae, with focus on the genus Peronospora. Phytopathology 2016, 106, 6-18. [CrossRef] [PubMed]

42. Zhang, Z.G.; Zheng, X.B.; Wang, Y.C.; Ko, W.H. Evaluation of the rearrangement of taxonomic position of Peronophythora litchii based on partial DNA sequences. Bot. Stud. 2007, 48, 79-89.

43. Ye, W.; Wang, Y.; Shen, D.; Li, D.; Pu, T.; Jiang, Z.; Zhang, Z.; Zheng, X.; Tyler, B.M.; Wang, Y. Sequencing of the litchi downy blight pathogen reveals it is a Phytophthora species with downy mildew-like characteristics. Mol. Plant-Microbe Interact. 2016, 29, 573-583. [CrossRef]

44. Ho, H.H.; Zheng, F.C.; Zheng, H.C. Phytophthora cyperi on Digitaria ciliaris in Hainan Province of China. Mycotaxon 2004, 90, 431-435.

45. Zheng, X.B.; Ho, H.H. The sexual stage of Phytophthora polygoni Saw. Bot Bull Acad Sin. 2000, 41, 57-60.

46. Göker, M.; Voglmayr, H.; Riethmüeller, A.; Weiß, M.; Oberwinkler, F. Taxonomic aspects of Peronosporaceae inferred from Bayesian molecular phylogenetics. Can. J. Bot. 2003, 81, 672-683. [CrossRef]

47. Thines, M.; Göker, M.; Oberwinkler, F.; Spring, O. A revision of Plasmopara penniseti, with implications for the host range of the downy mildews with pyriform haustoria. Mycol. Res. 2007, 111, 1377-1385. [CrossRef]

48. Thines, M.; Göker, M.; Telle, S.; Ryley, M.; Mathur, K.; Narayana, Y.D.; Spring, O.; Thakur, R.P. Phylogenetic relationships in graminicolous downy mildews based on cox2 sequence data. Mycol. Res. 2008, 112, 345-351. [CrossRef] [PubMed]

49. Gaümann, E.A. The Fungi. A Description of Their Morphological Features and Evolutionary Development; Hafner Publishing: New York, NY, USA; London, UK, 1952.

50. Waterhouse, G.M. Peronosporales. In The Fungi-An Advanced Treatise; Ainsworth, G.C., Sparrow, F.K., Sussman, A.S., Eds.; Academic Press: New York, NY, USA, 1973; pp. 165-183.

51. Dick, M.W.; Wong, P.T.W.; Clark, G. The identity of the oomycete causing kikuyu yellows with a reclassification of the downy mildews. Bot. J. Linn. Soc. 1984, 89, 171-198. [CrossRef]

52. Riethmüller, A.; Voglmayr, H.; Goker, M.; Weiss, M.; Oberwinkler, F. Phylogenetic relationships of the downy mildews (Peronosporales) and related groups based on nuclear large subunit ribosomal DNA sequences. Mycologia 2002, 94, 834. [CrossRef]

53. Runge, F.; Telle, S.; Ploch, S.; Savory, E.; Day, B.; Sharma, R. Thines M. The inclusion of downy mildews in a multi- locus-dataset and its reanalysis reveals a high degree of paraphyly in Phytophthora. IMA Fungus 2011, 2, 163-171. [CrossRef]

54. Martin, F.N.; Blair, J.E.; Coffey, M.D. A combined mitochondrial and nuclear multilocus phylogeny of the genus Phytophthora. Fungal Genet. Biol. 2014, 66, 19-32. [CrossRef]

55. Fletcher, K.; Gil, J.; Bertier, L.D.; Kenefick, A.; Wood, K.J.; Zhang, L.; Reyes-Chin-Wo, S.; Cavanaugh, K.; Tsuchida, C.; Wong, J.; et al. Genomic signatures of heterokaryosis in the oomycete pathogen Bremia lactucae. Nat. Commun. 2019, 10, 1-13. [CrossRef]

56. Butler, E.J. Report of the Imperial Mycologist, 1918-1919; Scientific Reports of the Agricultural Research Institute, Pusa: Calcutta, India, 1919; p. 82.

57. IDphy: Molecular and Morphological Identification of Phytophthora. Available online: https://idtools.org/id/phytophthora/ molecular.php (accessed on 8 September 2021).

58. Linaldeddu, B.T.; Bregant, C.; Ruzzon, B.; Montecchio, L. Coniella granati and Phytophthora palmivora the main pathogens involved in pomegranate dieback and mortality in north-eastern Italy. Ital. J. Mycol. 2020, 49, 92-100.

59. Kurbetli, İ.; Karaca, G.; Aydoğdu, M. Phytophthora species causing root and collar rot of pomegranate in Turkey. Eur. J. Plant. Pathol. 2020, 157, 485-496. [CrossRef]

60. Chliyeh, M.; Ouazzani Touhami, A.; Filali-Maltouf, A.; El Modafar, C.; Moukhli, A.; Oukabli, A.; Benkirane, R.; Douira, A. Phytophthora palmivora: A new pathogen of olive trees in Morocco. Atlas J. Biol. 2013, 2, 130-135. [CrossRef]

61. Cacciola, S.O.; Faedda, R.; Pane, A.; Scarito, G. Root and crown rot of olive caused by Phytophthora spp. In Olive Diseases and Disorders; Schena, L., Agosteo, G.E., Cacciola, S.O., Magnano di San Lio, G., Eds.; Transworld Research Network: Trivandrum, Kerala, India, 2011; pp. 305-327. 
62. Cacciola, S.O.; Gullino, M.L. Emerging and re-emerging fungus and oomycete soil-borne plant diseases in Italy. Phytopathol. Mediterr. 2019, 58, 451-472.

63. Brasier, C.M. The biosecurity threat to the UK and global environment from international trade in plants. Plant Pathol. 2008, 57, 792-808. [CrossRef]

64. Jung, T.; Orlikowski, L.; Henricot, B.; Abad-Campos, P.; Aday, A.G.; Aguin Casal, O.; Bakonyi, J.; Cacciola, S.O.; Cech, T.; Chavarriaga, D.; et al. Widespread Phytophthora infestations in European nurseries put forest, semi-natural and horticultural ecosystems at high risk of Phytophthora diseases. For. Pathol. 2016, 46, 134-163. [CrossRef]

65. Migliorini, D.; Ghelardini, L.; Tondini, E.; Luchi, N.; Santini, A. The potential of symptomless potted plants for carrying invasive soil-borne plant pathogens. Divers. Distrib. 2015, 21, 1218-1229. [CrossRef]

66. Drenth, A.; Guest, D. Phytophthora palmivora in Tropical Tree Crops. In Phytophthora-A Global Perspective; Lamour, K., Ed.; CABI: Oxfordshire, UK, 2013; pp. 187-196.

67. Mchau, G.R.A.; Coffey, M.D. Isozyme diversity in Phytophthora palmivora: Evidence for a Southeast Asian centre of origin. Mycol. Res. 1994, 98, 1035-1043. [CrossRef]

68. Zentmyer, G. Origin and distribution of four species of Phytophthora. Trans. Br. Mycol. Soc. 1988, 91, 367-378. [CrossRef]

69. Brasier, C.M.; Vettraino, A.M.; Chang, T.T.; Vannini, A. Phytophthora lateralis discovered in an old growth Chamaecyparis forest in Taiwan. Plant Pathol. 2010, 59, 595-603. [CrossRef]

70. Jung, T.; Chang, T.T.; Bakonyi, J.; Seress, D.; Pérez-Sierra, A.; Yang, X.; Hong, C.; Scanu, B.; Fu, C.H.; Hsueh, K.L.; et al. Diversity of Phytophthora species in natural ecosystems of Taiwan and association with disease symptoms. Plant Pathol. 2017, 66, 194-211. [CrossRef]

71. Jung, T.; Horta Jung, M.; Webber, J.F.; Kageyama, K.; Hieno, A.; Masuya, H.; Uematsu, S.; Pérez-Sierra, A.; Harris, A.R.; Forster, J.; et al. The Destructive Tree Pathogen Phytophthora ramorum Originates from the Laurosilva Forests of East Asia. J. Fungi 2021, 7, 226. [CrossRef]

72. Shakya, S.K.; Grünwald, N.J.; Fieland, V.J.; Knaus, B.J.; Weiland, J.E.; Maia, C.; Drenth, A.; Guest, D.I.; Liew, E.C.Y.; Crane, C.; et al. Phylogeography of the wide-host range panglobal plant pathogen Phytophthora cinnamomi. Mol Ecol. 2021, 30, 5164-5178. [CrossRef]

73. Grünwald, N.J.; McDonald, B.A.; Milgroom, M.G. Population genomics of fungal and oomycete pathogens. Ann. Rev. Phytopat. 2016, 54, 323-346. [CrossRef]

74. Ali, S.; Shao, J.; Lary, D.; Strem, M.; Meinhardt, L.; Bailey, B. Phytophthora megakarya and P. palmivora, Causal Agents of Black Pod Rot, Induce Similar Plant Defense Responses Late during Infection of Susceptible Cacao Pods. Front. Plant Sci. 2017,8 , 169. [CrossRef]

75. Jung, T.; Horta Jung, M.; Scanu, B.; Seress, D.; Kovács, G.M.; Maia, C.; Pérez-Sierra, A.; Chang, T.T.; Chandelier, A.; Heungens, K.; et al. Six new Phytophthora species from ITS Clade 7a including two sexually functional heterothallic hybrid species detected in natural ecosystems in Taiwan. Persoonia 2017, 38, 100-135. [CrossRef]

76. Burgess, T.I. Molecular characterization of natural hybrids formed between five related indigenous Clade 6 Phytophthora species. PLoS ONE 2015, 10, e0134225. [CrossRef]

77. Van Poucke, K.; Haegeman, A.; Goedefroit, T.; Focquet, F.; Leus, L.; Horta Jung, M.; Nave, C.; Redondo, M.A.; Husson, C.; Kostov, K.; et al. Unravelling hybridization in Phytophthora using phylogenomics and genome size estimation. IMA Fungus 2021, 12, 16 [CrossRef]

78. Guo, Y.; Sakalidis, M.L.; Torres-Londoño, G.A.; Hausbeck, M. Population structure of a worldwide Phytophthora palmivora collection suggests lack of host specificity and reduced genetic diversity in South American and Caribbean. Plant Dis. 2021. [CrossRef] [PubMed]

79. FAOSTAT. Crops and Livestock Products. 2021. Available online: http:/ /www.fao.org/faostat/en/\#data/QCL (accessed on 8 September 2021).

80. Kurbetli, I.; Sulu, G.; TaŞtekİn, E.; Polat, I. First report of Phytophthora inundata causing olive tree decline in Turkey. Can. J. Plant Pathol. 2016, 38, 254-257. [CrossRef]

81. González, M.; Pérez-Sierra, A.; Serrano, M.S.; Sanchez, M.E. Two Phytophthora species causing decline of wild olive (Olea europaea subsp. europaea var. sylvestris). Plant Pathol. 2017, 66, 941-948. [CrossRef]

82. Ruano-Rosa, D.; Schena, L.; Agosteo, G.E.; Magnano di San Lio, G.; Cacciola, S.O. Phytophthora oleae sp. nov. causing fruit rot of olive in southern Italy. Plant Pathol. 2018, 67, 1362-1373. [CrossRef]

83. Linaldeddu, B.T.; Bregant, C.; Montecchio, L.; Favaron, F.; Sella, L. First report of Phytophthora acerina, P. pini and P. plurivora causing root rot and sudden death on olive trees in Italy. Plant Dis. 2020, 104, 996. [CrossRef]

84. Santilli, E.; Riolo, M.; La Spada, F.; Pane, A.; Cacciola, S.O. First report of root rot caused by Phytophthora bilorbang on Olea europaea in Italy. Plants 2020, 9, 826. [CrossRef] [PubMed] 